\title{
Strengthening research capacity through regional partners: the HRP Alliance at the World Health Organization
}

Richard Adanu', Luis Bahamondes ${ }^{2}$, Vanessa Brizuela ${ }^{3^{*}}$ (D), Evelyn Gitau ${ }^{4}$, Seni Kouanda ${ }^{5}$, Pisake Lumbiganon ${ }^{6}$, Thi Thuy Hanh Nguyen ${ }^{7}$, Sarah Saleem ${ }^{8}$, Anna Thorson ${ }^{3}$ and Kwasi Torpey ${ }^{1}$

\begin{abstract}
Background: Improvements in health cannot occur without cutting-edge research informing the design and implementation of health programmes and policies, highlighting the need for qualified and capable researchers and institutions in countries where disease burden is high and resources are limited.

Main body: Research capacity strengthening efforts in low- and middle-income countries have included provision of training scholarships for postgraduate degrees, often in high-income countries, internships at research universities/centres, short courses, as well as involvement with research groups for hands-on experience, among others. The HRP Alliance provides opportunities for developing local research capacity in sexual and reproductive health and rights through institutions based in low- and middle-income countries linked with ongoing and past collaborative studies. It is a network of HRP research partner institutions, World Health Organization (WHO) country and regional offices, WHO special programmes and partnerships, and WHO collaborating centres.

Conclusion: It is through the HRP Alliance that HRP seeks to improve population health by strengthening local research capacity in sexual and reproductive health across the globe, with focus in low- and middle-income countries, in alignment with WHO's quest of promoting healthier populations.
\end{abstract}

Keywords: Research capacity strengthening, Research, Sexual and reproductive health, LMIC

\section{Résumé}

Introduction: II ne peut y avoir d'amélioration en matière de santé sans une recherche de pointe qui éclaire la conception et la mise en oeuvre des programmes et des politiques de santé, en soulignant la nécessité de disposer de chercheurs et d'institutions qualifiés et compétents dans les pays où la charge de morbidité est élevée et où les ressources sont limitées.

\footnotetext{
* Correspondence: brizuelav@who.int

${ }^{3}$ UNDP/UNFPA/UNICEF/WHO/World Bank Special Programme of Research, Development and Research Training in Human Reproduction (HRP),

Department of Sexual and Reproductive Health and Research, World Health

Organization, Avenue Appia 20, 1211 Geneva, Switzerland

Full list of author information is available at the end of the article
}

(c) The Author(s). 2020 Open Access This article is licensed under a Creative Commons Attribution 4.0 International License, which permits use, sharing, adaptation, distribution and reproduction in any medium or format, as long as you give appropriate credit to the original author(s) and the source, provide a link to the Creative Commons licence, and indicate if changes were made. The images or other third party material in this article are included in the article's Creative Commons licence, unless indicated otherwise in a credit line to the material. If material is not included in the article's Creative Commons licence and your intended use is not permitted by statutory regulation or exceeds the permitted use, you will need to obtain permission directly from the copyright holder. To view a copy of this licence, visit http://creativecommons.org/licenses/by/4.0/ The Creative Commons Public Domain Dedication waiver (http://creativecommons.org/publicdomain/zero/1.0/) applies to the data made available in this article, unless otherwise stated in a credit line to the data. 
(Continued from previous page)

Texte principal: Parmi les efforts de renforcement des capacités de recherche dans les pays à faible revenu et pays à revenu intermédiaire (PFR-PRI), figurent l'octroi de bourses de formation pour des diplômes de troisième cycle, souvent dans des pays à revenu élevé, des stages dans des universités/centres de recherche, des cours de courte durée, ainsi que la participation à des groupes de recherche pour une expérience pratique, entre autres. L'Alliance HRP offre des possibilités de développement des capacités de recherche locales en matière de santé et des droits sexuels et reproductifs (SDSR), par l'intermédiaire d'institutions basées dans les pays à revenu faible et intermédiaire, en lien avec les études collaboratives en cours et passées. II s'agit d'un réseau d'institutions partenaires de recherche du HRP, de bureaux nationaux et régionaux de I'OMS, de programmes spéciaux et de partenariats de l'OMS et de centres collaborateurs de l'OMS.

Conclusion: C'est par l'intermédiaire de l'Alliance HRP que le HRP cherche à améliorer la santé des populations en renforçant les capacités de recherche locales en matière de SDSR dans le monde entier, en particulier dans les PRF-PRI, conformément à la mission de l'OMS de promouvoir la bonne santé des populations.

Mots clés: Renforcement des capacités de recherche, Recherche, Santé sexuel et reproductif, PFR-PRI

\section{Resumo}

Introducção: As melhorias na saúde não podem ocorrer sem as pesquisas de ponta que informam o planejamento e a implementação de programas e políticas de saúde, evidenciando a necessidade de pesquisadores e instituições capazes e qualificadas em países onde a incidência de doença é alta, e os recursos são limitados.

Texto principal: $\mathrm{O}$ empenho pelo reforço da capacidade de pesquisa em países de baixa e média renda (LMIC) tem incluído provisões de bolsas de formação para pós-graduação, geralmente em países de renda alta, estágios em universidades/centros de pesquisas, cursos de curta duração, assim como envolvimento com grupos de pesquisas para experiência prática, entre outros. A HRP Alliance fornece oportunidades para o desenvolvimento de capacidade de pesquisa local em saúde e direitos sexuais e reprodutivos (SRHR) através de instituições estabelecidas em países de baixa e média renda ligados a estudos colaborativos anteriores e em andamento. É uma rede de instituições parceiras HRP, escritórios nacionais e regionais da OMS, programas e parcerias especiais e centros colaborativos da OMS.

Conclusão: É através da HRP Alliance que o desenvolvimento e treinamento em pesquisa em reprodução humana (HRP) busca melhorar a saúde da população pelo reforço local na capacidade de pesquisa em SRHR em todo o mundo, com foco nos LMIC, em alinhamento com a busca da OMS em promover populações mais saudáveis.

Palabras chave: Reforço da capacidade de pesquisa, Pesquisa, Saúde sexual e reprodutiva, Países de baixa e média renda

\section{Resumen}

Introducción: Las mejoras en la salud no pueden suceder sin investigaciones de vanguardia que informen sobre el diseño y la implementación de programas y políticas de salud y que pongan énfasis en la necesidad de contar con investigadores e instituciones capaces y competentes en los países donde la carga de morbilidad es alta y los recursos son limitados.

Texto principal: Los esfuerzos para el fortalecimiento de la capacidad de investigación en los países de ingresos bajos y medianos incluyeron, entre otros, el ofrecimiento de becas de capacitación a graduados universitarios, a menudo en países de ingresos altos, pasantías en universidades y centros de investigación, cursos breves y también participación en grupos de investigación para experiencias prácticas. La Alianza HRP ofrece oportunidades para el desarrollo de capacidades de investigación locales en salud y derechos sexuales y reproductivos (SDSR) a través de instituciones ubicadas en países de ingresos bajos y medianos vinculadas con estudios colaborativos presentes y pasados. Se trata de una red de instituciones asociadas de investigación del Programa de Reproducción Humana (HRP), oficinas regionales y nacionales de la OMS, programas y asociaciones especiales de la OMS y centros colaboradores de la OMS.

Conclusión: A través de la Alianza HRP, el HRP busca mejorar la salud de la población con el fortalecimiento de la capacidad de investigación local en SDSR en todo el mundo, centrado en los países de ingresos bajos y medianos, y alineado con la misión de la OMS de promover poblaciones más saludables.

Palabras clave: Fortalecimiento de la capacidad de Investigación, Investigación, Salud sexual y reproductiva, Países de ingresos bajos y medianos 


\section{Background}

Improvements in health cannot occur without cuttingedge research informing the design and implementation of health programmes and policies. Evidence generated in-country is necessary to shape and add relevance to national research and policy agendas [1-3]. This highlights the need for qualified and capable researchers and institutions in countries where disease burden is high and resources are limited. The inverse relationship between sexual and reproductive health and rights (SRHR)-related disease burden and availability of research capacity is recognised and different efforts have been undertaken to strengthen capacity in low-andmiddle-income countries (LMIC) over the last few decades [4].

\section{Main body}

Research capacity strengthening (RCS) efforts in LMICs have included provision of training scholarships for postgraduate degrees, often in high-income countries, internships at research universities/centres, short courses, as well as involvement with research groups for hands-on experience, among others [5-7]. These efforts have resulted in producing researchers for LMICs but have not always significantly built the capacity of LMIC institutions to conduct their own research to identify solutions or monitor uptake and use of evidence for better SRHR outcomes [6]. Sustainable RCS should develop the capacity of target institutions in countries in need so they can successfully train competent researchers, and respond to local, regional, and global agendas $[5,6]$. While currently there are well-established research institutes in LMICs that can train and conduct high quality research, there are still gaps with regards to strengthening the research capacity of junior researchers. Ensuring equitable and fair authorship is also critical to developing local RCS $[8-10]$.

\section{The HRP Alliance}

The HRP Alliance, created in 2016 as part of the UNDP/ UNFPA/UNICEF/WHO/World Bank Special Programme of Research, Development and Research Training in Human Reproduction (HRP) [11], provides opportunities for developing local research capacity through institutions linked with ongoing and past collaborative studies (visit website using this link https://www.who.int/reproductivehealth/hrp_alliance/en/). It is a network of HRP research partner institutions, WHO country and regional offices, WHO special programmes and partnerships, and WHO collaborating centres. It is through the HRP Alliance that HRP seeks to improve population health by strengthening local research capacity in SRHR across the globe, with focus in LMICs, in alignment with WHO's quest of promoting healthier populations [12]. (See Table 1). Despite
Table 1 The HRP Alliance - vision, mission, strategy, goals and core values

\section{Vision}

The HRP Alliance aims to improve sexual and reproductive health and rights (SRHR) globally by strengthening research capacity.

Mission

To support institutions to develop high quality research capacity in SRHR.

Strategy

By linking research capacity strengthening (RCS) with HRP research and knowledge transfer, the HRP Alliance capitalizes and reinforces existing collaborations. It provides support for institutions to position themselves in the global SRHR research and knowledge transfer arena. This is provided through long-term institutional grants to research institutions selected as regional RCS hubs supporting other institutions in their respective regions.

Goals

1- To strengthen SRHR research capacity in an alliance of institutions and stakeholders in LMICs

2- To improve institutions' own research infrastructure

3- To strengthen research capacity of the institutions in the region through trainings, courses, and formal education of individuals

4- To link HRP research with HRP Alliance partners on SRHR topics

5- To lead in knowledge translation activities

6- To build a critical mass of world class researchers in SRHR

implementation research around the globe

7- To support research in humanitarian or emergency SRHR issues Core values

- Focus on gender equality

- Promote rights-based research

- Lead in high level implementation research

- Foster knowledge translation among a global network of SRHR researchers

Website: https://www.who.int/reproductivehealth/hrp_alliance/en/

the recent creation of the HRP Alliance, HRP has been leading RCS efforts for several decades. In the past, this has been done through long-term institutional development grants which focused mostly on individual institutional strengthening and support of local research projects. The focus now, through the HRP Alliance, lies on building a regional critical mass of researchers supported by institutions located in the regions, illustrating a true horizontal collaboration among researchers.

At the core of the HRP Alliance are regional RCS "hubs," selected through an open competitive process that considers experience in SRHR RCS and capacity to provide regional leadership in RCS. These hubs, based in Brazil, Burkina Faso, Ghana, Kenya, Pakistan, Thailand, and Viet Nam, ${ }^{1}$ are entrusted with providing RCS support to institutions in their regions. While the HRP Alliance is still in its nascent stages, support is provided primarily through:

\footnotetext{
${ }^{1}$ Brazil: Centro de Pesquisas em Saúde Reprodutiva de Campinas CEMICAMP; Burkina Faso: Institut de Recherche en Sciences de la Santé - IRSS; Ghana: University of Ghana School of Public Health UGSPH; Kenya: African Population Health Research Center - APHRC; Pakistan: Aga Khan University - AKU; Thailand: Khon Kaen University - KKU; and Viet Nam: Hanoi Medical University - HMU.
} 


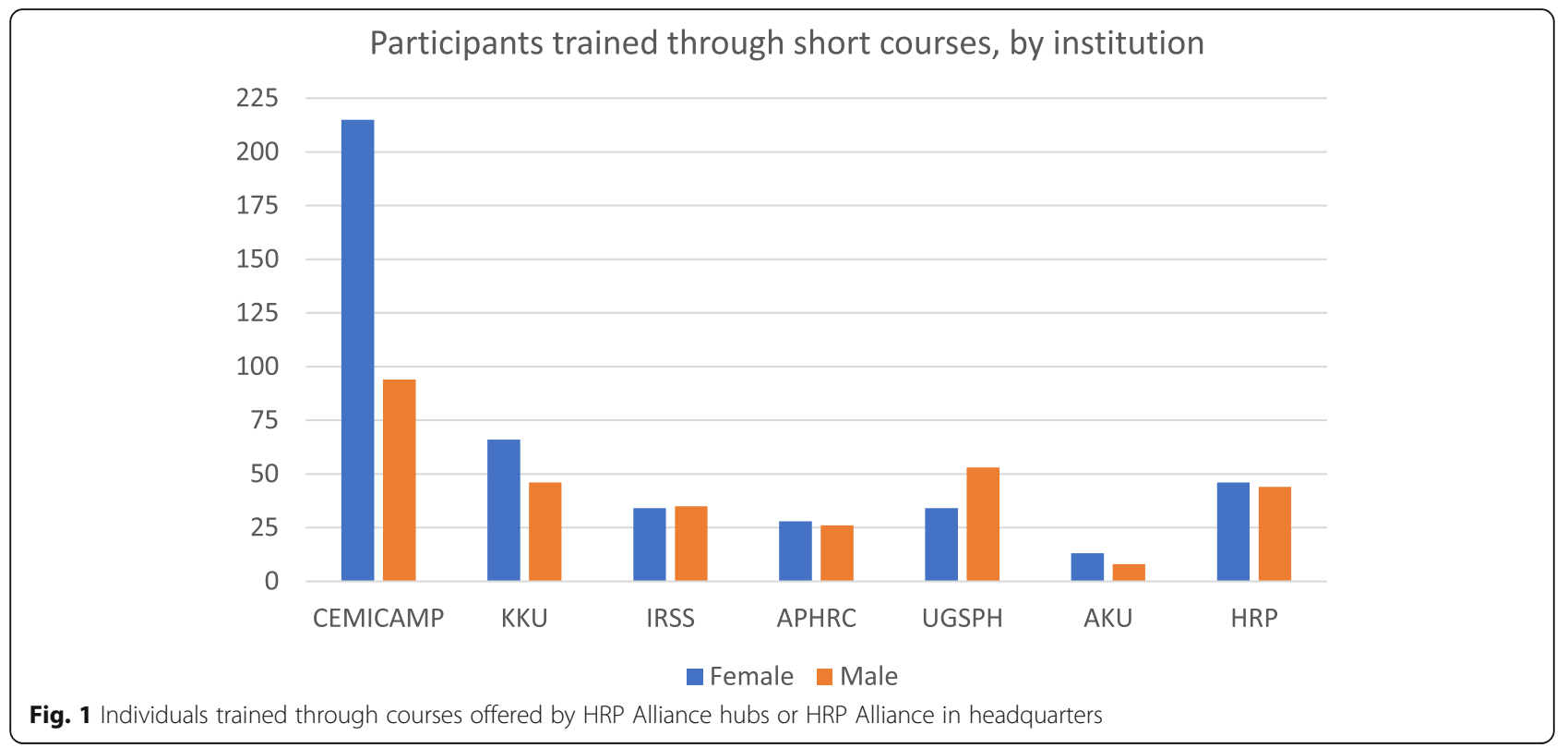

- Workshops and trainings on SRHR, research methodologies and biostatistics, systematic review and meta-analysis, qualitative research methods, implementation research, monitoring and evaluation, protocol development and manuscript writing (Fig. 1);

- Post-graduate education specific to SRHR research (through masters and/or doctoral degrees) (Fig. 2);

- Tailored support to country research institutions in the development and implementation of research studies and the production of scientific publications;
- Leadership in knowledge transfer activities that contribute to ensuring the implementation of WHO recommendations for policy and practice;

- Collaborative grant proposals among several hubs or institutions supported by the hubs using the HRP Alliance network to leverage experience and expertise;

- Enabled collaborations among HRP Alliance fellows for specific research projects;

- Response to health emergencies through SRHR research to improve rapid health system response and local research capacity.

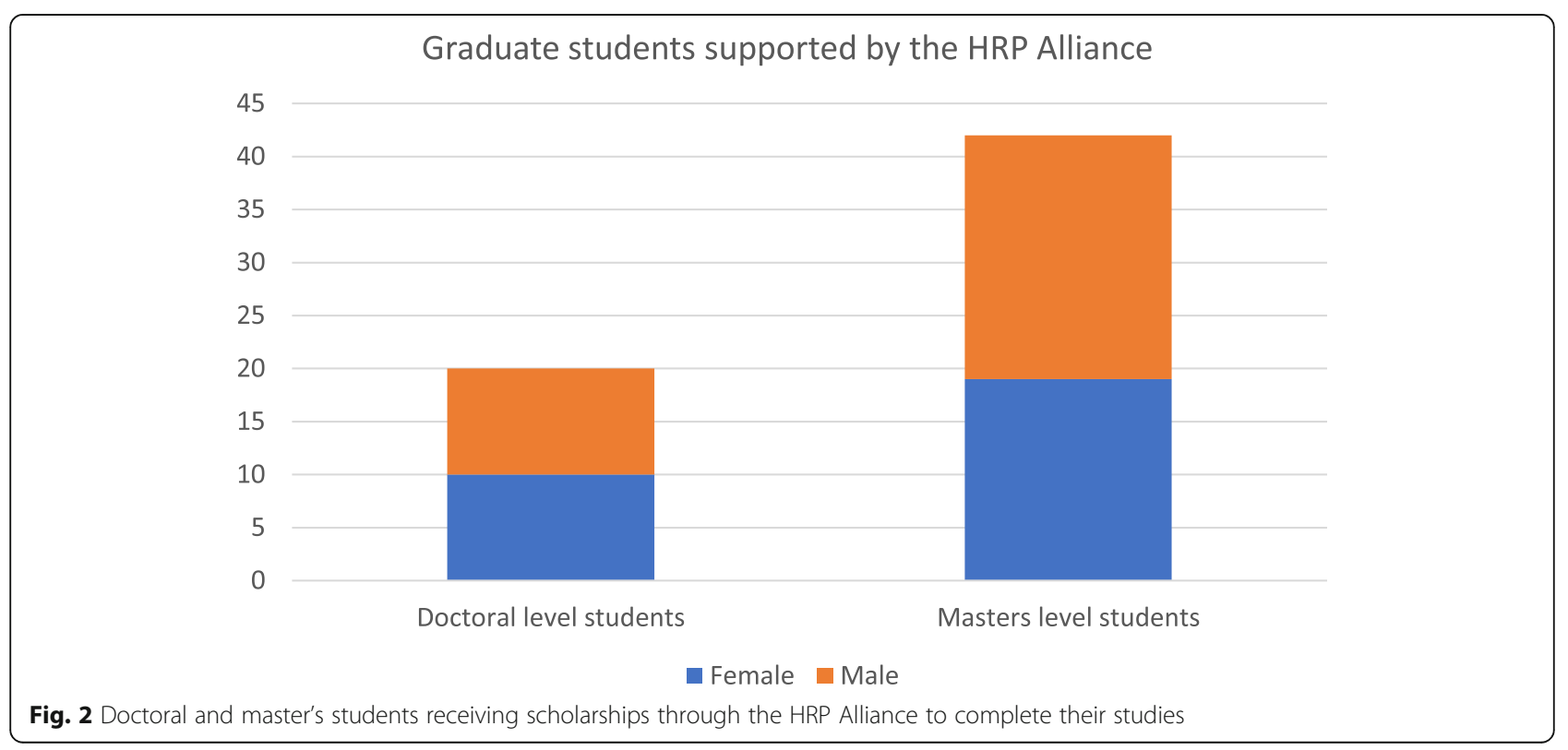


Since inception, the HRP Alliance has trained over 700 participants from LMICs through 30 workshops and courses and is supporting over 60 researchers obtain a master's or doctoral degree, some of whom have been involved in the local implementation of HRP multi-country studies [13-17] and in secondary analyses. The HRP Alliance supports the use of group authorship for multi-country studies, local leadership in secondary and country-specific analyses, and the establishment of authorship rules and roles prior to project start-up. Over 20 research groups from Latin America have been funded by the HRP Alliance to provide the evidence base to respond to the Zika virus epidemic in 2016-2017 [18] and the mass migration crisis in the Americas in 2019-2020. The HRP Alliance also swiftly responds to the needs arising from health and humanitarian emergencies according to the specific needs for RCS and research. In the upcoming years, the HRP Alliance will support junior researchers through a tailored mentorship programme for women and postdoctoral fellowships as well as support additional research to study the SRHR of migrants in the Eastern Mediterranean region.

\section{Conclusion}

The HRP Alliance model for RCS is one among many, but it holds the unique characteristic of allowing for the development and building of research capacity of individuals and institutions through the engagement and leadership of research institutions located in LMICs. This model has the potential, by supporting RCS activities through institutions located in the regions of interest, to prevent future brain drain of qualified researchers by building capacity and offering viable opportunities for implementing research in their home countries. This paper serves as a blueprint of what the HRP Alliance has set out to do and to be held accountable to its mandate.

\section{Supplementary information}

Supplementary information accompanies this paper at https://doi.org/10. 1186/s12978-020-00965-0.

Additional file 1. Version de l'article en français - versão do artigo em português - versión del artículo en español

\section{Abbreviations \\ HRP: Human Reproduction Programme, the UNDP/UNFPA/UNICEF/WHO/ World Bank Special Programme of Research, Development and Research Training in Human Reproduction; LMIC: low- and middle-income countries; $R C S$ : research capacity strengthening; SRHR: sexual and reproductive health and rights; WHO: World Health Organization}

\section{Acknowledgements}

The authors wish to thank lan Askew for his support of the HRP Alliance and all the research institutions with whom they work globally.

\section{Authors' contributions}

RA developed the first versions of this commentary with substantial contributions from AT and VB. LB, EG, SK, PL, TTHN, SS, and KT provided additional feedback on final versions of this manuscript. All authors read and approved the final version.

\section{Funding}

The HRP Alliance is funded by the UNDP/UNFPA/UNICEF/WHO/World Bank Special Programme of Research, Development and Research Training in Human Reproduction (HRP). The views of the funding body have not influenced the content of this manuscript. This article represents the views of the named authors only and does not represent the views of WHO.

\section{Availability of data and materials}

Not applicable.

Ethics approval and consent to participate

Not applicable.

\section{Consent for publication}

Not applicable.

\section{Competing interests}

$\mathrm{RA}, \mathrm{VB}$ and AT were employed at HRP/WHO at the time of writing this commentary. LB, EG, SK, PL, TTHN, SS, and KT were coordinating the HRP Alliance hubs in their institutions which were receiving funds for execution of activities. All authors declare no competing interests.

\section{Author details}

${ }^{1}$ Department of Population, Family and Reproductive Health, University of Ghana School of Public Health, Accra, Ghana. ${ }^{2}$ Department of Obstetrics and Gynaecology, University of Campinas Medical Faculty, Campinas, SP, Brazil. ${ }^{3}$ UNDP/UNFPA/UNICEF/WHO/World Bank Special Programme of Research, Development and Research Training in Human Reproduction (HRP), Department of Sexual and Reproductive Health and Research, World Health Organization, Avenue Appia 20, 1211 Geneva, Switzerland. ${ }^{4}$ African Population and Health Research Center, Nairobi, Kenya. ${ }^{5}$ Institut de Recherche en Sciences de la Santé (IRSS), Ouagadougou, Burkina Faso. ${ }^{6}$ Department of Obstetrics and Gynaecology, Faculty of Medicine, Khon Kaen University, Khon Kaen, Thailand. 'Institute for Preventive Medicine and Public Health, Hanoi Medical University, Hanoi, Viet Nam. ${ }^{8}$ Department of

Community Health Sciences, Aga Khan University, Karachi, Pakistan.

Received: 28 May 2020 Accepted: 27 July 2020

Published online: 26 August 2020

\section{References}

1. World Health Organization, editor. Research for universal health coverage, in The world health report. Geneva: WHO; 2013. p. 146.

2. Chu KM, Jayaraman S, Kyamanywa P, Ntakiyiruta G. Building research capacity in Africa: Equity and Global Health Collaborations. PLoS Med. 2014; 11(3):e1001612.

3. Belizán JM, Miller S. What can WHO do to support research in LMICs?. The Lancet. 2017;389(10080):1697.

4. Kabra R, Castillo M, Melián M, Ali M, Say L, Gulmezoglu AM. Research capacity strengthening for sexual and reproductive health: a case study from Latin America. Reprod Health. 2017:14:35.

5. Tulloch-Reid MK, Gore Saravia N, Dennis RJ, Jaramillo A, Cuervo LG, Walker $\mathrm{SP}$, et al. Strengthening institutional capacity for equitable health research: lessons from Latin America and the Caribbean. BMJ. 2018;362:k2456.

6. Bowsher G, Papamichail A, El Achi N, Ekzayez A, Roberts B, Sullivan R, et al. A narrative review of health research capacity strengthening in low and middle-income countries: lessons for conflict-affected areas. Globalization and health. 2019;15(1):23.

7. Matus J, Walker A, Mickan S. Research capacity building frameworks for allied health professionals-a systematic review. BMC Health Serv Res. 2018;18(716).

8. Kelaher M, Ng L, Knight K, Rahadi A. Equity in global health research in the new millennium: trends in first-authorship for randomized controlled trials among low- and middle-income country researchers 1990-2013. Int J Epidemiol. 2016;45(6):2174-83. 
9. Hedt-Gauthier BL, Jeufack HM, Neufeld NH, Alem A, Sauer S, Odhiambo J, et al. Stuck in the middle: a systematic review of authorship in collaborative health research in Africa, 2014-2016. BMJ Glob Health. 2019;4(5):e001853.

10. Iyer AR. Authorship trends in the lancet Global Health. Lancet Glob Health. 2018;6(2):e142.

11. WHO | HRP Alliance. WHO. [cited 2018 Jan 6]. Available from: http://www. who.int/reproductivehealth/hrp_alliance/en/.

12. Thirteenth general programme of work 2019-2023. [cited 2019 Dec 11]. Available from: https://www.who.int/about/what-we-do/thirteenth-generalprogramme-of-work-2019-2023.

13. Kim CR, Tunçalp Ö, Ganatra B, Gülmezoglu AM, Group WM-AR. WHO multicountry survey on abortion-related morbidity and mortality in health facilities: study protocol. BMJ Glob Health. 2016;1 (3):e000113.

14. Bonet M, Brizuela V, Abalos E, Cuesta C, Baguiya A, Chamillard M, et al. Frequency and management of maternal infection in health facilities in 52 countries (GLOSS): a 1-week inception cohort study. Lancet Glob Health. 2020;8(5):e661-71.

15. Tran NT, Seuc A, Coulibaly A, Landoulsi S, Millogo T, Sissoko F, et al. Postpartum family planning in Burkina Faso (yam Daabo): a two group, multiintervention, single-blinded, cluster-randomised controlled trial. Lancet Glob Health. 2019;7(8):e1109-17.

16. Bohren MA, Mehrtash H, Fawole B, Maung TM, Balde MD, Maya E, et al. How women are treated during facility-based childbirth in four countries: a cross-sectional study with labour observations and community-based surveys. Lancet. 2019;394(10210):1750-63.

17. Maung TM, Show KL, Mon NO, Tunçalp Ö, Aye NS, Soe YY, et al. A qualitative study on acceptability of the mistreatment of women during childbirth in Myanmar. Reprod Health. 2020;17(1):56.

18. Thorson A, Aslanyan G, Brizuela V, Perez F, Gómez Ponce de León R, Reeder $J C$, et al. Research and research capacity strengthening in the context of an emerging epidemic: Zika virus in Latin America. International Journal of Gynecology \& Obstetrics. 2020;148(S2):1-3.

\section{Publisher's Note}

Springer Nature remains neutral with regard to jurisdictional claims in published maps and institutional affiliations.

Ready to submit your research? Choose BMC and benefit from:

- fast, convenient online submission

- thorough peer review by experienced researchers in your field

- rapid publication on acceptance

- support for research data, including large and complex data types

- gold Open Access which fosters wider collaboration and increased citations

- maximum visibility for your research: over $100 \mathrm{M}$ website views per year

At $\mathrm{BMC}$, research is always in progress.

Learn more biomedcentral.com/submissions 